\title{
Management of ankle sprains during pregnancy: evaluation of 96 cases
}

\author{
Çetin Işık, M.D., ${ }^{1}$ Mesut Tahta, M.D., ${ }^{2}$ Derya Işık, M.D., ${ }^{3}$ Yusuf Üstü, M.D., ${ }^{4}$ \\ Mehmet Uğurlu, M.D., ${ }^{4}$ Nuray Bozkurt, M.D., ${ }^{5}$ Murat Bozkurt, M.D. ${ }^{6}$

\begin{abstract}
${ }^{1}$ Department of Orthopaedics and Traumatology, Ankara Atatürk Training and Research Hospital, Ankara;
${ }^{2}$ Department of Orthopaedic and Trauma Clinic, Igdır State Hospital, Igdır;

${ }^{3}$ Department of Familiy Medicine, Ankara Atatürk Training and Research Hospital, Ankara;

${ }^{4}$ Department of Familiy Medicine, Yıldırım Beyazıt University Faculty of Medicine, Ankara Atatürk Training and Research Hospital, Ankara;

${ }^{5}$ Department of Obstetrics And Gynecology, Gazi University Faculty of Medicine, Ankara;

${ }^{6}$ Department of Orthopaedics and Traumatology, Yıldırım Beyazıt University Faculty of Medicine,
\end{abstract} \\ Ankara Atatürk Training and Research Hospital, Ankara
}

\begin{abstract}
BACKGROUND: The aim of this study was to suggest a safe management method for the diagnosis and treatment of ankle sprains in pregnant patients.

METHODS: Between November 2005 and January 2013, 96 pregnant patients with ankle sprains referred to the department of orthopedics and traumatology were evaluated, retrospectively. The Ottawa ankle rules were used to assess the need for radiologic evaluation. Radiological procedures: Surface USG, X-ray $(0,6 \mathrm{mGy}$, mortise view), MRI (TI and STIR) and fluoroscopy with 0,8 mGy/s doses $0,4 \mathrm{~ms}$ single shot views in surgery room. The results of the operated patients were evaluated with AOFAS scoring system.
\end{abstract}

RESULTS: Forty-four $(\% 45,8)$ patients were treated with conservative methods and there was no need for radiological evaluation. USG was used in 17 (\% I 7,7), MRI in 24 (\%25), X-ray in 4 (\%4,I) and both USG and MRI in 7 (\%7,2) patients during diagnosis. An algorithm was created for the diagnosis and treatment of pregnant patients with ankle sprains. No complications due to radiological and surgical procedures occurred over pregnancies. The AOFAS score was 83 (65-100) in the operated patients.

CONCLUSION: There is no standard management method for the diagnosis and treatment of pregnant patients with ankle sprains. The algorithm presented in this study may be useful. Good results can be obtained with an appropriate preparation and surgical technique.

Key words: Ankle; ankle sprains; pregnancy; radiation.

\section{INTRODUCTION}

Ankle injuries comprise approximately $2.15 / 1000$ of all bodily injuries and are particularly seen in young adults. ${ }^{[1,2]}$ Of these injuries, 174/100,000 result in fractures. ${ }^{[3]}$ The majority of

Address for correspondence: Çetin Işı, M.D.

Ankara Atatürk Eğitim ve Araştırma Hastanesi,

Ortopedi ve Travmatoloji Kliniği, Ankara, Turkey

Tel: +90 312 - 3629675 E-mail: ortdrcetin@hotmail.com

Qucik Response Code Ulus Travma Acil Cerrahi Derg

20। 4; 20 (4):275-280

doi: $10.5505 /$ tjtes.20|4.949|4

Copyright 2014

TJTES sprained ankles are evaluated and treated in the emergency department. The most common injury is an "inversion injury," when the foot in plantar. ${ }^{[4]}$

Ankle sprains in pregnancy, which require direct radiographs present particular difficulties because of the side-effects of radiation on the fetus. The potential effects of radiation on a growing fetus include prenatal mortality, delayed intrauterine growth, mental retardation, organ malformation, and the development of cancer in childhood. ${ }^{[5]}$

Physicians facing these risks generally avoid the taking of radiographs and may make errors resulting in serious disabilities as ultrasonography (USG) and magnetic resonance imaging (MRI) are not of sufficient benefit. Moreover in literature, there is no detailed information and standardization of the path to follow in such situations. 
This study aimed to show a safe and standard route to reaching diagnosis in pregnant patients with a sprained ankle and to evaluate the results of the treatment applied to patients requiring surgical treatment.

\section{MATERIALS AND METHODS}

A retrospective evaluation was made of 96 pregnant patients who presented at the emergency Department of Ankara Dışkapı Yıldırım Beyazıt Training and Research Hospital with the complaint of a sprained ankle and underwent consultation in the Orthopedic and Traumatology Clinic between November 2005 and January 2013. Number of patients who felt no need for consultation and treatment could not be determined due to defects of archiving system of emergency department. Thirteen patients were excluded from the study if direct radiographs or any other imaging had been taken before consultation with the orthopedic and traumatology clinic. The mean age of the patients was 28 years (range: 21-36 years). Seventeen of the patients were in the first trimester of pregnancy, 46 were in the second trimester and 33 were in the third trimester. The complaints and history of trauma of all the patients were recorded. In the physical examination, the points of pain were determined and syndesmosis injury and instability were evaluated. The need for any imaging method to be applied was determined using the Ottawa ankle criteria (OAC). MRI was applied to patients with deformity, abnormal movement, crepitation or certain indications of fracture such as palpation of fracture (Fig. I). To determine a fracture on MRI, only $\mathrm{TI}$ and short $\mathrm{TI}$ inversion recovery sequences were taken.

As the effect of MRI on pregnancy is unknown, patients in the first trimester were dressed in a lead apron and a mortise anterior-posterior direct radiograph was taken of the ankle

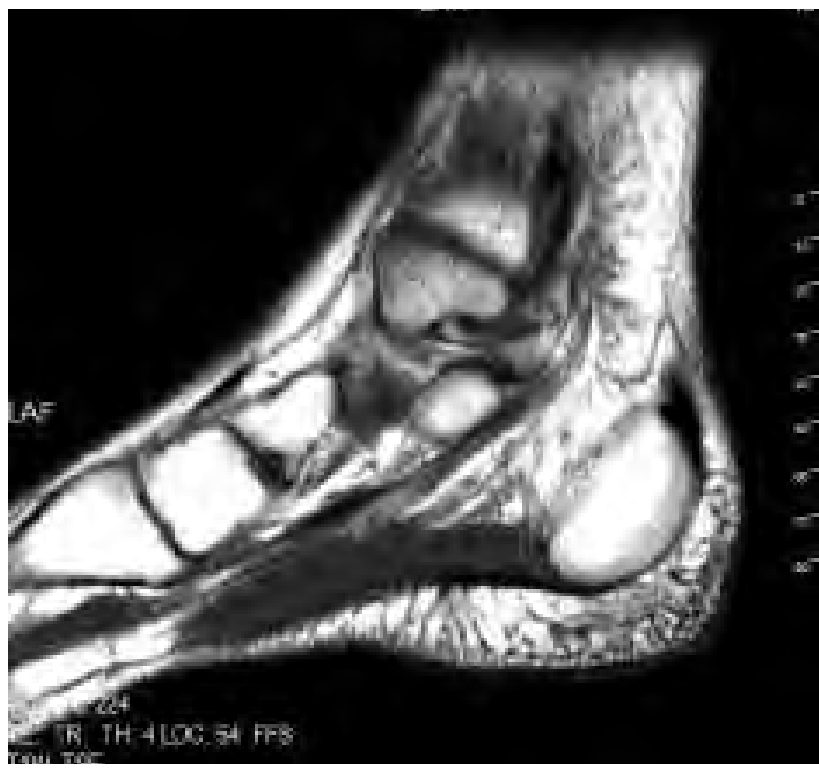

Figure 1. Fracture clearly shown on T1 magnetic resonance imaging sequences.

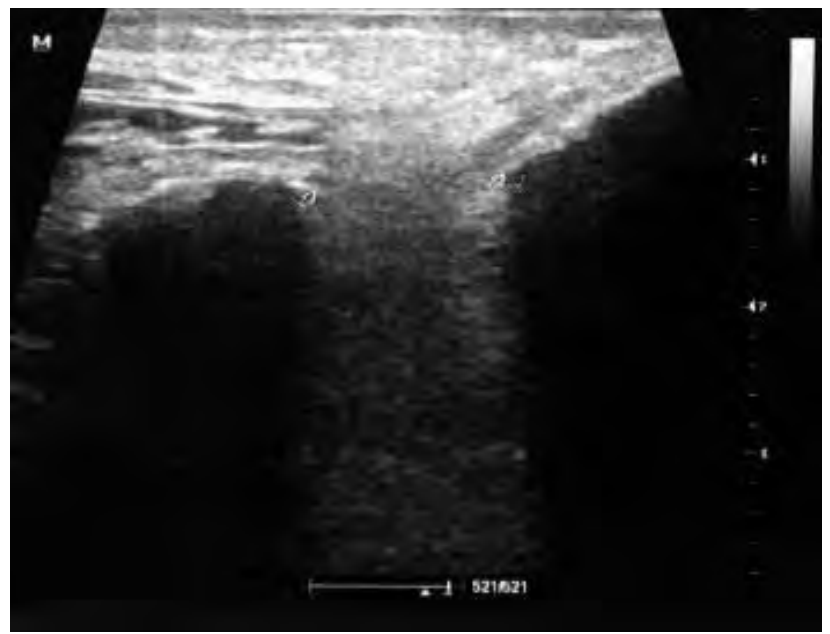

Figure 2. Ultrasonography image of lateral malleolar fracture.

only in $15^{\circ}$ internal rotation at a dosage of maximum 0.6 $\mathrm{mGy}$, rather than the application of MRI. For patients without definite fracture indications, but who required radiological evaluation as a result of the physical examination, superficial USG was firstly applied (Fig. 2). With USG, the bone cortex discontinuity and superficial ligaments such as the deltoid ligament and the anterior talofibular ligament were evaluated.

Then patients were physically examined again. At this stage, MRI was applied additional to the USG in patients where it was seen to be necessary. There was not felt to be any need for computerized tomography for any patient. All the patients determined with a fracture were classified according to the Lauge-Hansen Classification and the mechanism of trauma was recorded. Of these patients, those with appropriate indications for surgical treatment were admitted for surgery in the shortest possible time. The algorithm followed for diagnosis and treatment is given schematically in Fig. 3. Spinal anesthesia was preferred for all patients. All patients were dressed in a lead apron before staining and draping (Fig. 4). Preoperative I g cephalosporin prophylaxis and I g 2x|/24 hours postoperative antibiotic treatment was applied to all patients. Fluoroscopy was only used when necessary during surgery at a dose of $0.8 \mathrm{mGy} / \mathrm{s}$ in single applications of 0.4 ms, a maximum of twice on the same patient. Mechanical and pharmacological prophylaxis for deep venous thrombosis was applied and early mobilization was provided for all patients. Following surgery, the patients were followed up in respect of the outcome of the pregnancy and surgical results. At the final follow up examination, the ankles of the patients who underwent surgery were evaluated with the American Orthopedic Foot and Ankle Society (AOFAS) score.

\section{RESULTS}

Of the 96 patients evaluated with the complaints of sprained ankle, 44 (45.8\%) were not felt to be in need of any imaging method and were treated conservatively (cold compress, el- 


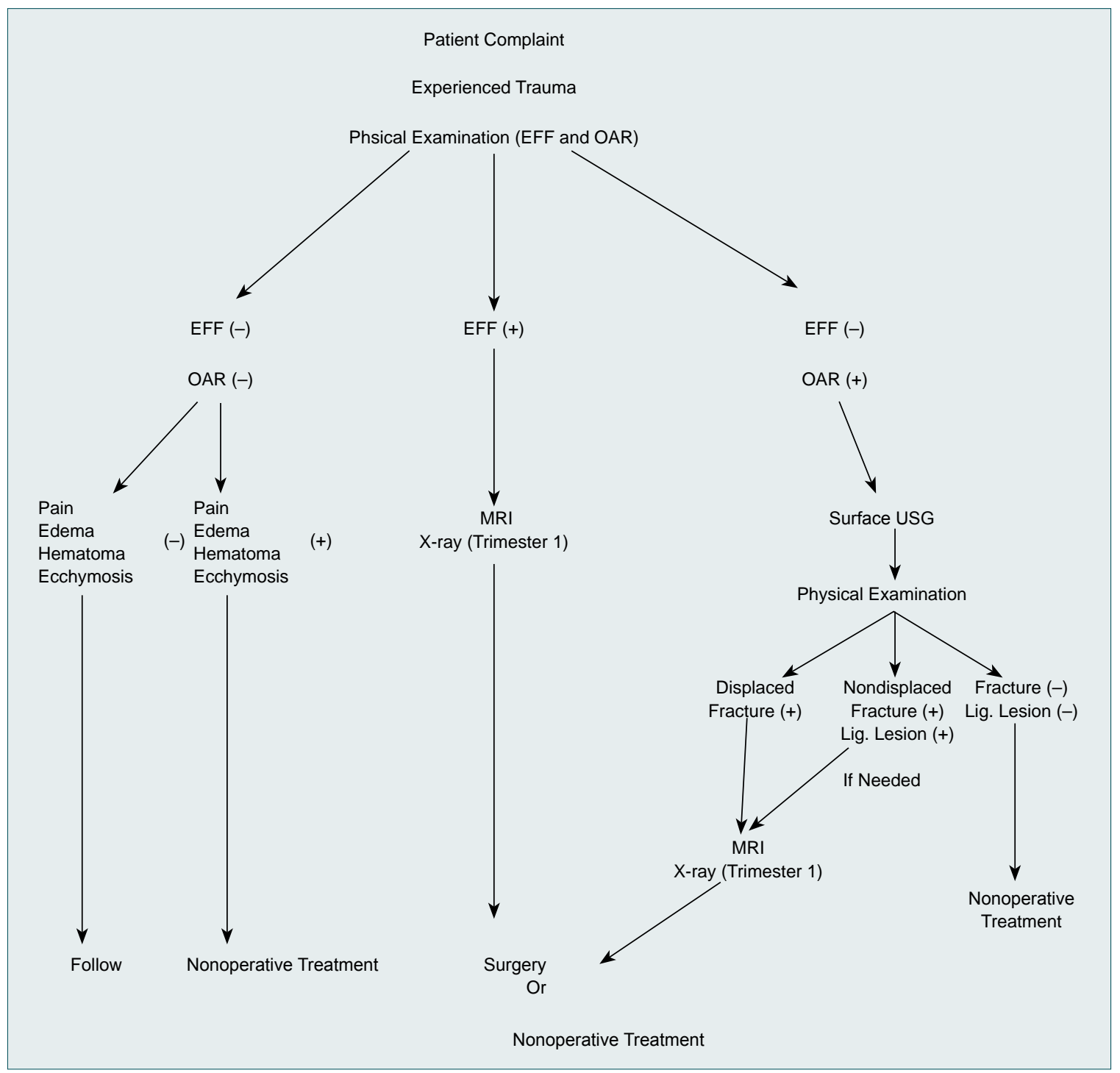

Figure 3. Schematic representation of the diagnostic and treatment algorithm that was followed.

evation, bandage, rest, medical treatment). All patients were recommended to follow polyclinic visits. However, there were 15 patients who couldn't be reached or didn't come to visits. Of the other 52 patients, MRI was applied to 24 of 28 patients with definite fracture indications and for four patients in the first trimester, a lead apron was worn and a mortise radiograph of the ankle only was taken at a low dose. After physical examination, 24 patients who did not have definite indications of fracture, but required a direct radiograph according to the OAC were firstly evaluated with superficial USG. In 17 patients (17.7\%), the USG images were seen to be sufficient.

While no bone pathology was determined in $1 \mathrm{I}(\mathrm{II} .4 \%)$ of these patients, in 5 (5.2\%) below the level of syndesmosis in the lateral malleolus and in one patient in the medial malleolus, a $1 \mathrm{~mm}$ discontinuation of the cortex was determined, which was evaluated as non-displaced fracture. A short-leg circular plaster cast was applied to patient determined with bone pathology and a short-leg plaster splint was applied to the others. In two patients with no bone pathology, MRI was required during follow up and they were treated conservatively. In the remaining seven patients, MRI was required additional to USG (Table I).

In the 35 (36.4\%) patients to whom MRI and direct radiographs were applied, there was an isolated malleolar fracture

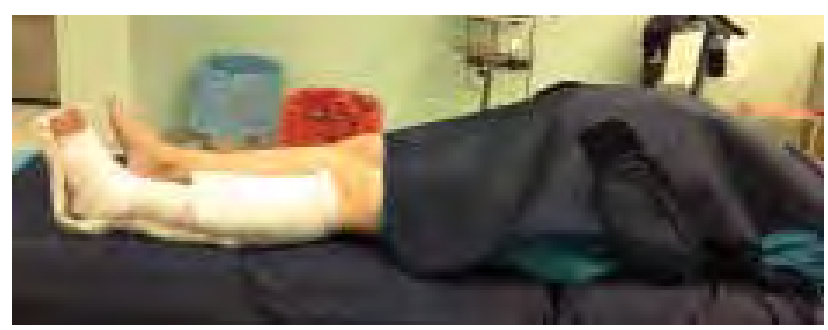

Figure 4. A lead apron was worn preoperatively by all pregnant patients. 
Table I. The distribution of patients according to the need for radiological examination

\begin{tabular}{lllllll}
\hline & Total & Radiological examination (-) & \multicolumn{2}{l}{ Radiological examination (+) } \\
\hline Number of patients & 96 & $44(\% 45.8)$ & $52(\% 54.2)$ & & & \\
\cline { 2 - 6 } & & & USG I7 & MRI 24 & X-ray 4 & USG+MRI \\
& & & $(\% 17.7)$ & $(\% 25)$ & $(\% 4.1)$ & $7(\% 7.2)$ \\
\hline
\end{tabular}

USG: Ultrasonography; MRI: Magnetic resonance imaging.

Table 2. The distribution of patients according to the treatment protocol

\begin{tabular}{lccc}
\hline & $\begin{array}{c}\text { EFF (-) } \\
\text { OAR (-) } \\
\text { (number of patients) }\end{array}$ & $\begin{array}{c}\text { EFF (+) } \\
\text { (number of patients) }\end{array}$ & $\begin{array}{r}\text { EFF (-) } \\
\text { OAR (+) } \\
\text { (number of patients) }\end{array}$ \\
\hline Total & 44 & 28 & 24 \\
X-ray & - & 4 & - \\
Ultrasonography & - & - & 24 \\
Magnetic resonance imaging & - & 24 & 7 \\
Conservative treatment & 44 & 7 & 18 \\
Surgical treatment & - & 21 & 6 \\
\hline
\end{tabular}

EFF: Exact fracture findings; OAR: Ottawa ankle rules.

in $2 \mathrm{I}$ below, above or at the syndesmosis level. Bimalleolar fractures were determined in nine patients and trimalleolar in five patients. In the treatment of eight of the 14 patients with a fracture at the level of syndesmosis, the syndesmosis was seen to be healthy and a short-leg circular plaster cast was applied. The remaining 27 (28.1\%) patients were prepared for surgery (Table 2). Supination+adduction injuries were present in 13 patients, supination+external rotation in eight and pronation+external rotation in six. Four of the patients were in the first trimester, 15 in the second trimester and eight in the third trimester.

Spinal anesthesia was preferred for all patients. Staining and draping procedures were made with the patient wearing a lead apron. Fluoroscopy was not used at all in five of the six patients with a lateral malleolar fracture and it was not necessary to be used more than twice in the remaining patients. For all the patients, the utmost care was taken in the decision as to whether fluoroscopy was necessary. Postoperatively, there was no necessity to terminate any of the pregnancies. In the follow up no complications in the pregnancies were encountered which could have arisen from the surgical treatment. At the final examination, the mean AOFAS score of all patients was 83 (range, 65-100); the mean AOFAS score was 88 (range, 70-100) in those with a single malleolar fracture; 81 (range, 65-100) in those with a bimalleolar fracture, and 79 (range, 65-95) in those with a trimalleolar fracture.

\section{DISCUSSION}

We think that the algorithm, we defined is going to fill an important space about the management of sprained ankles during pregnancy. The most important specification of this algorithm is to provide protection for pregnant patients from radiation in all steps. In addition, the results show that this algorithm is an easy-applicable way of treating patients.

The majority of sprained ankles can be successfully treated in the emergency department. When diagnosis cannot be clearly made, when there is indecision as to the need for imaging techniques, and when there are definite indications of a fracture, an Orthopedic and Traumatology specialist should be consulted to make an accurate diagnosis and define the correct approach for treatment. Physical examination is extremely important in the approach to sprained ankles. This is even more important in situations where there is a risk in taking direct radiographs, such as in pregnancy. With the application of the OAC, exposure to radiation is significantly reduced without compromising diagnostic thoroughness, time is saved and healthcare costs are reduced. ${ }^{[6,7]}$

In a study by Jenkin et al., ${ }^{[8]}$ OAC sensitivity was reported to be $98 \%$. In the current study, there was no problem about 29 patients whose OAC (-) and who wasn't felt to be any need for any imaging study. However, because of 15 "lost" patients with OAC (-), an exact percentage couldn't be given. It was considered necessary to apply the OAC to the ankle sprains 
of pregnant patients. As seen in this study, the treatment of $45.8 \%$ of the patients was made without the application of direct radiographs to those who might be affected teratogenically and without MRI in the first trimester for which the effects are not clearly known. For those who required radiological evaluation, a graduated approach was preferred. Thus, diagnosis was made in $17.7 \%$ of cases from superficial USG only, without direct radiographs or MRI. While the effect of $M R I$ in the first trimester is not clear, pregnant patients are exposed to radiation with direct radiographs. The dose of radiation exposed to is important.

In a study by McCollough et al., ${ }^{[9]}$ no malformation was reported in $95.8 \%$ of fetuses from a dose of $100 \mathrm{mGy}$ radiation and no childhood cancer developed in $99.7 \%$ and it was emphasized that doses below $50 \mathrm{mGy}$ can be disregarded. In the same study, it was stated that there was a minimal effect on the fetus of radiation focused on the abdomen and pelvis as the dose reaching the fetus in radiography, fluoroscopy, and tomography in these regions rarely exceeds $25 \mathrm{mGy}$. In the current study, a maximum dose of $0.6 \mathrm{mGy}$ was used for the ankle anterior-posterior radiographs. In addition, all patients wore a lead apron to achieve the minimum effect from radiation to the embryo or fetus. In patients undergoing surgery, fluoroscopy was only used at a dose of $0.8 \mathrm{mGy}$ and $0.4 \mathrm{~ms}$ single image twice at the most, in cases thought to be at risk of the screw penetrating the joint in the reduction of the fracture line. For all the patients to be minimally affected, a lead apron was worn before the operation started.

The treatment choices for sprained ankles differ according to the form and nature of the injury. Conservative treatment can be selected for injuries with no accompanying fracture, when the syndesmosis integrity is not impaired, for non-displaced stable fractures and for displaced fractures where stable anatomic reduction of the ankle mortise can be achieved. ${ }^{[10]}$ Surgical treatment is preferred for fractures where reduction cannot be achieved or sustained, where there is talus displacement and expansion in the ankle mortise and where reduction can only be achieved with the foot in an abnormal position. ${ }^{[1]}$

Surgical indications do not change in pregnancy so the surgical indications cannot be avoided. Persistence in conservative treatment of fractures which require surgery can have catastrophic results. In the current study, the mean AOFAS score of the patients who underwent surgery was evaluated as 83 (good). With Lauge-Hansen supination-adduction injury, the AOFAS score mean was 90 (70-100); with supination-external rotation and pronation-external rotation injury the AOFAS score was 79 (65-100). The reason for the high rate of patients undergoing surgical treatment in the current study (28/96 cases, $29.1 \%$ ) may be that the majority of cases treated conservatively or who were not felt to need treatment were evaluated in the emergency department without being sent to the Orthopedic and Traumatology Department for consultation.

The current study would be more valuable if there was more study in the literature. Studies with wide numbers of patients will be useful.

That there is no standardization in the literature for an approach to sprained ankles in pregnant patients leaves physicians in a difficult situation. The current study can be of use in respect of the graduated approach, which was applied and the diagnosis and treatment algorithm defined herein. The indications for surgical treatment of a sprained ankle do not change in pregnancy and good results can be obtained with surgery and careful preparation.

\section{Conflict of interest: None declared.}

\section{REFERENCES}

1. Waterman BR, Owens BD, Davey S, Zacchilli MA, Belmont PJ Jr. The epidemiology of ankle sprains in the United States.J Bone Joint Surg Am 2010;92:2279-84. CrossRef

2. Tiemstra JD. Update on acute ankle sprains. Am Fam Physician 2012;85:1170-6.

3. Kannus $\mathrm{P}$, Palvanen $\mathrm{M}$, Niemi S, Parkkari J, Järvinen M. Increasing number and incidence of low-trauma ankle fractures in elderly people: Finnish statistics during 1970-2000 and projections for the future. Bone 2002;31:430-3. CrossRef

4. Struijs PA, Kerkhoffs GM. Ankle sprain. Clin Evid (Online) 2010;05:1115.

5. Wagner LK, Lester RG, Saldana LR. Exposure of the pregnant patient to diagnostic radiations: a guide to medical management. Madison, Wis: Medical Physics Publishing; 1997.

6. Aginaga Badiola JR, Ventura Huarte I, Tejera Torroja E, Huarte Sanz I, Cuende Garcés A, Gómez Garcerán M, et al. Validation of the Ottawa ankle rules for the efficient utilization of radiographies in acute lesions of the ankle. [Article in Spanish] Aten Primaria 1999;24:203-8. [Abstract]

7. Dowdall H, Gee M, Brison RJ, Pickett W. Utilization of radiographs for the diagnosis of ankle fractures in Kingston, Ontario, Canada. Acad Emerg Med 2011;18:555-8. CrossRef

8. Jenkin M, Sitler MR, Kelly JD.Clinical usefulness of the Ottawa Ankle Rules for detecting fractures of the ankle and midfoot. J Athl Train 2010;45:480-2. CrossRef

9. McCollough CH, Schueler BA, Atwell TD, Braun NN, Regner DM, Brown DL, et al. Radiation exposure and pregnancy: when should we be concerned? Radiographics 2007;27:909-18. CrossRef

10. Dietrich A, Lill H, Engel T, Schönfelder M, Josten C. Conservative functional treatment of ankle fractures. Arch Orthop Trauma Surg 2002;122:165-8. CrossRef

11. Michelson JD. Fractures about the ankle. J Bone Joint Surg Am 1995;77:142-52. 


\section{KLINIK ÇALIŞMA - ÖZET}

\section{Gebelikte ayak bileği burkulmalarına yaklaşım ve tedavi: 96 olgunun değerlendirilmesi Dr. Çetin Işık, ${ }^{1}$ Dr. Mesut Tahta, ${ }^{2}$ Dr. Derya Işık, ${ }^{3}$ Dr. Yusuf Üstü, ${ }^{4}$ Dr. Mehmet Uğurlu, ${ }^{4}$ Dr. Nuray Bozkurt, ${ }^{5}$ Dr. Murat Bozkurt ${ }^{6}$}

${ }^{1}$ Ankara Atatürk Eğitim ve Araştırma Hastanesi, Ortopedi ve Travmatoloji Kliniği, Ankara;

${ }^{2}$ Iğdır Devlet Hastanesi, Ortopedi ve Travmatoloji Kliniği, Iğdır;

${ }^{3}$ Ankara Atatürk Eğitim ve Araştırma Hastanesi, Aile Hekimliği Kliniği, Ankara;

${ }^{4}$ Yıldırım Beyazıt Üniversitesi Tıp Fakültesi, Ankara Atatürk Eğitim ve Araştırma Hastanesi, Aile Hekimliği Kliniği, Ankara;

${ }^{5}$ Gazi Üniversitesi Tıp Fakültesi, Kadın Hastalıkları ve Doğum Anabilim Dalı, Ankara;

${ }^{6}$ Yıldırım Beyazıt Üniversitesi Tıp Fakültesi, Ankara Atatürk Eğitim ve Araştırma Hastanesi, Ortopedi ve Travmatoloji Kliniği, Ankara

AMAÇ: Bu çalışmada ayak bileği burkulması olan gebelerde tanıya ulaşmada ve tedavide güvenli, standart bir yol göstermeyi ve uyguladığımız cerrahi tedavinin sonuçlarını değerlendirmeyi amaçladık.

GEREÇ VE YÖNTEM: Kasım 2005-Ocak 2013 tarihleri arasında ayak bileği burkulması şikayeti ile başvurup Ortopedi ve Travmatoloji Kliniği'ne konsülte edilen 96 gebe geriye dönük olarak değerlendirildi. Ottawa Ayak Bileği Kriterleri (OABK) kullanılarak hastalarda görüntüleme yöntemi gereği olup olmadığı belirlendi. Radyolojik inceleme olarak yüzeyel USG, direkt grafi (0.6 mGy'yi geçmeyecek dozda sadece Mortis grafisi), MRG (sadece TI ve STIR) ve ameliyathanede $0.8 \mathrm{mGy} / \mathrm{s}$ dozunda, 0.4 ms'lik tek çekimler şeklinde floroskopi kullanıldı. Cerrahi tedavi uygulanan hastalar gebeliklerinin akıbeti, cerrahinin sonuçları ve AOFAS skoru ile değerlendirildi.

BULGULAR: Doksan altı hastanın 44’ü (\%45.8) bir görüntüleme yöntemine başvurma gereği duyulmadan konservatif yöntemlerle tedavi edildi. Geri kalan 52 hastanın I7'sinde (\%।7.7) USG, 24'ünde (\%25) MRG, dördünde (\%4.I) direkt grafi ve yedisinde (\%7.2) USG+MRG ile tanıya ulaşıldı. Bu tür hastalarda izlenebilecek bir tanı ve tedavi algoritması oluşturuldu. Ameliyat sonrası hastaların hiçbirinde gebeliğin sonlandırılması gereği duyulmadı ve cerrahi tedavinin gebelikleri üzerinde yol açtığı bir komplikasyona rastlanmadı. Cerrahi tedavi uygulanan hastaların ortalama AOFAS Skoru 83 (65-100) bulundu.

TARTIŞMA: Gebelikte ayak bileği burkulmalarına yaklaşımda literatürde standardizasyon yoktur. Çalışmamızda uyguladığımız tanı ve tedavi algoritması bu açıdan faydalı olabilir. Cerrahi tedavide, dikkatli hazırlık ve teknik ile iyi sonuçlar alınmaktadır.

Anahtar sözcükler: Ayak bileği; ayak bileği yaralanmaları; gebelik; radyasyon.

Ulus Travma Acil Cerrahi Derg 20।4;20(4):275-280 doi: 10.5505/tjtes.20।4.949|4 